\title{
Going short on biotech
}

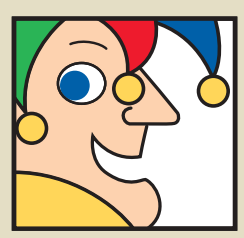

Tom Jacobs, of the Internet site Motley Fool (http://www.fool.com/), provides his angle on biotechnology investments. Read on and become "Foolishly" informed*. He can be contacted about biotechnology and investing at TomJ@Fool.com. Jacobs cannot give individual investment advice but welcomes any.

You already know you can make money when a stock goes up, but you can also profit when the price declines. In the up-and-down world of biotech, this method—shorting stocks—-may hold some appeal for experienced investors. Yet, investors at all levels can improve by being aware of what shorting is and how much of a stock is sold short.

\section{What is shorting?}

When you buy the stock of a business you believe will prosper, you bet that over time the stock will rise to reflect the business' increased worth. You have gone 'long,' or are holding a long position. But if your research shows you that a business is ailing and its stock should follow, you can sell the stock short and profit 'from the disease.'

Shorting is like borrowing your aunt's newly released set of DVDs for Brideshead Revisited and selling it to your neighbor. You then find one on eBay for less and return it to your aunt, pocketing the difference. As an investor, you enter a sell short order. You don't own the stock, so your broker must borrow it. When you want to close out a long position, you sell the stock. To close a short position, you must buy the stock for return to the lender. When you do, you pocket the difference if the stock has gone down, or pay out of pocket if the stock has risen.

\section{Why shorting can hurt}

There are three major risks. First, the long-term direction of the market has been upwards. If that continues, it means that even if your research is wrong about a company, the rising tide may yet lift the leaky boat you hope will sink (everyone's a genius in a bull market). While a down market can help a short position in the same way, over time there have been far more and longer bull markets than bear. The wind is against you.

Second, when you have a long position, you can never lose more than you invest. The worst that can happen-and it's painful-is that the stock goes to zero. But when you short, the stock can rise and rise into infinity. Your loss is theoretically unlimited, and your gain-if the stock goes to zero-can never be more than $100 \%$.

Third, you may be forced to buy to cover your short position at a time and price that give you a substantial loss. News or other events may so drive demand for a stock that the lender of your shares wants them back

* Nature Biotechnology does not guarantee the veracity, reliability, or completeness of any information provided on this page; it is not responsible for any errors or omissions or for any results obtained from the use of such information; it will not be liable for any loss, damage, or investment decision arising from a reader's reliance on the information provided. to sell them to someone else, or good news drives investors to cover short positions en masse. In this short squeeze, the price spikes up and you can sell, if at all, only at a worse loss.

\section{Float and days to cover}

That's why those looking to short or those who hold a short position track two measures of potential trouble. First, not the number of company shares shorted, but rather the percentage of the float (outstanding shares available for sale) short. Second, days to cover, or how many days it would take at the stock's average daily trading volume for every short share to be covered. If, say, the percentage of float short is higher than single digits, and/or days to cover is more than a week, good news affecting the stock could find you in the middle of a short squeeze. You can find percentage of float short on most online financial sources and days to cover on the Nasdaq site, http://www.nasdaq.com/.

\begin{tabular}{lccc} 
Table 1 Short interest & & & \\
Company & $\begin{array}{l}\text { Number of } \\
\text { shares sold } \\
\text { short (millions) }\end{array}$ & $\begin{array}{l}\text { Float } \\
\text { short (\%) }\end{array}$ & $\begin{array}{l}\text { Days } \\
\text { to cover }\end{array}$ \\
\hline Biosite (San Diego, CA, USA; Nasdaq:BSTE) & 6.7 & $51 \%$ & 13 \\
VaxGen (Brisbane, CA, USA; Nasdaq:VXGN) & 2.6 & $49 \%$ & 10 \\
Trimeris (Durham, NC, USA; Nasdaq:TRMS) & 6.1 & $31 \%$ & 11 \\
Genta (Berkeley Heights, NJ, USA; Nasdaq:GNTA) & 12.1 & $31 \%$ & 12 \\
Cell Therapeutics (Seattle, WA, USA; NasdaqNM:CTIC) & 9.0 & $29 \%$ & 22 \\
Ligand Pharmaceuticals (San Diego, CA, USA; Nasdaq:LGND) & 10.0 & $24 \%$ & 11 \\
Biopure (Cambridge, MA, USA; Nasdaq:BPUR) & 8.7 & $23 \%$ & 10 \\
ViroPharma (Exton, PA, USA; Nasdaq:VPHM) & 2.9 & $22 \%$ & 6 \\
OXiGENE (Watertown, MA, USA; Nasdaq:OXGN) & 2.6 & $21 \%$ & 6 \\
Albany Molecular Research (Albany, NY, USA; Nasdaq:AMRI) & 2.8 & $19 \%$ & 21 \\
Genentech (S. San Francisco, CA, USA; NYSE:DNA) & 9.5 & $5 \%$ & 4 \\
Biogen (Cambridge, MA, USA; NasdaqNM:BGEN) & 6.1 & $4 \%$ & 2 \\
Amgen (Thousand Oaks, CA, USA; NasdaqNM:AMGN) & 28.2 & $2 \%$ & 4
\end{tabular}

\section{Short biotech?}

Table 1 shows the numbers of shares short, percentage of float short and days to cover for the top ten shorted biotechs (and three well-known biotech drug makers). In this group are those arguably considered either overvalued or in trouble. But shorting for the first reason-valuation only-isn't very smart. Sure, biotech companies as a whole have rocketed since March lows, and you may quite reasonably think they are due for a retreat. That's great. However, why can't the same irrational winds that drove stocks higher blow longer and cause shorts great pain? Those who remember the last bull market may ask how many people sold at the top. Because few can time the market, it's best to short only companies whose businesses appear headed for disaster.

\section{Shorting to your advantage}

You can be a better investor by examining the percentage of float short and days to cover for any company you own or are thinking of buying. If many are headed in the short direction and you want to go long, check your research. Either you find something you missed, or gain even more confidence in your position-secure that your glasses do not have a rosy tint to them. 